\title{
Jual Rugi Pada Persaingan Usaha Fotocopy Di Lingkungan Kampus Iain Langsa (Perspektif Uu No. 5 Tahun 1999 Dan Fiqh)
}

\author{
Oleh : Adelina Nasution \\ IAIN Langsa \\ adelinanasution@iainlangsa.ac.id
}

\begin{abstract}
Abstrak:
Jual rugi yang dilakukan oleh pengusaha fotocopy dengan cara menetapkan harga yang sangat rendah dengan maksud untuk menyingkirkan atau mematikan usaha pesaingnya, bertentangan dengan isi Undang-undang No. 5 Tahun 1999 Pasal 20 yang menyebutkan bahwa pelaku usaha dilarang melakukan jual rugi atau menetapkan harga yang sangat rendah dengan maksud untuk menyingkirkan atau mematikan usaha pesaingnya.Islam menyambut baik sistem persaingan dalam melakukan usaha, karena pada dasarnya Islam tetap memiliki prinsip kebebasan dalam melakukan berbagai kegiatan mu'amalah termasuk di dalamnya persaingan, akan tetapi persaingan harus sesuai dengan syari'ah. Persaingan yang terjadi pada usaha fotocopy di lingkungan IAIN Langsa di mana harga yang ditetapkan pendatang baru sangat rendah, yang mengakibatkan pengusaha lama kehilangan pelanggan dan menutup usahanya. Persaingan ini menimbulkan ketidak adilan yang dirasakan oleh pengusaha fotocopy, tindakan tersebut tidak sesuai dengan maqashid syari'ah, dan memberikan mudharat kepada diri sendiri juga kepada pengusaha lain.
\end{abstract}

\section{A.Pendahuluan}

Undang-undang Nomor 5 Tahun 1999 tentang Larangan Praktek Monopoli dan Persaingan Usaha Tidak Sehat dalam pasal 20 salah satunya menyatakan tentang jual rugi atau predatory pricing, yaitu cara yang dilakukan oleh pengusaha dengan menetapkan harga yang sangat rendah dengan maksud untuk menyingkirkan atau mematikan usaha pesaingnya.

Jual rugi ini dilakukan oleh pengusaha fotocopy di lingkungan IAIN Langsa terutama dilakukan oleh pendatang baru, karena memang usaha fotocopy ini sangat menguntungkan dan masih tetap menjanjikan dan selalu memiliki pasar, maka pesaing dalam usaha ini pun semaikin bertambah. Banyak pendatang baru yang melakukan jual rugi dan merusak harga pasar yang menyebabkan kemudharatan kepada pengusaha lainnya dan dirasakan tidak adil yang menyebabkan hilangnya 
maqashid syariah yang ingin dicapai dari kegiatan jual beli tersebut. Dan kenyataannya di lapangan pesaing lama dan bahkan pesaing baru yang melakukan jual rugi tersebut akhirnya ada yang gulung tikar karena tidak sanggup lagi menghadapi pasar tersebut.

Metode yang dipakai dalam tulisan ini adalah metode penelitian normatif. ${ }^{1}$ Jenis penelitian yang dimaksud adalah jenis penelitian dengan menggunakan metode atau cara yang dipergunakan di dalam penelitian hukum yang dilakukan dengan cara meneliti bahan pustaka. Dan juga digunakan metode empiris dengan melihat kenyataan yang terjadi di lapangan, yaitu persaingan usaha fotocopy di lingkungan kampus IAIN Langsa.

\section{B.Pengertian Jual Rugi (Predatory Pricing)}

Jual rugi (predatory pricing, yakni dengan cara menetapkan harga ${ }^{2}$ yang sangat rendah dengan maksud untuk menyingkirkan atau mematikan usaha pesaingnya, karena tidak mampu lagi untuk bersaing. ${ }^{3}$

Berdasarkan teori ekonomi jual rugi adalah suatu kondisi di mana suatu pelaku usaha menetapkan harga jual dari barang dan/atau jasa yang diproduksinya di bawah biaya total rata-rata (Average Total Cost). Suatu pelaku usaha hanya akan memperoleh keuntungan jika ia dapat menetapkan harga jual barang dan/atau jasa yang diproduksinya di atas biaya total rata-rata, atau hanya dapat sekedar menutup biayanya (pulang pokok-break even) apabila menetapkan harga persis sama dengan biaya total rata-rata. Namun, harga yang ditetapkan di bawah biaya total rata-rata (ATC) tersebut tetap masih dapat dikatakan sebagai reasonable price apabila

\footnotetext{
${ }^{1}$ Penelitian ini pada hakekatnya merupakan suatu penelitian hukum yang dikerjakan dengan tujuan menemukan asas atau donktrin hukum positif yang berlaku. Lihat, Faisar Ananda Arfa dan Watni Marpaung, Metodologi Penelitian Hukum Islam (Jakarta: Kencana, 2016), h. 41 ; Soerjono Soekanto dan Sri Mamudji, Penelitian Hukum Normatif Suatu Timjuan Singkat (Jakarta: PT RajaGrafindo Persada, 2006), h., 13.

${ }^{2}$ Harga adalah sesuatu yang bernilai yang harus direlakan oleh pembeli untuk memperoleh barang atau jasa. Harga jual produk mempunyai fungsi ganda. Fungsi pertama adalah sarana untuk memenangkan persaingan di pasar. Fungsi kedua, harga adalah sumber keuntungan perusahaan. Menurut Basu Swasta DH dan Irawan, harga adalah jumlah uang yang dibutuhkan untuk mendapatkan sejumlah kombinasi dari barang beserta pelayanannya. Lihat, Basu Swasta DH dan Irawan, Asas-asas Marketing (Yogyakarta: Liberty, 1964), h., 147.

${ }^{3}$ Rachmadi Usman, Hukum Persaingan Usaha di Indonesia (Jakarta: Sinar Grafika, 2013), h., 435.
} 
berada di atas biaya variabel rata-rata (Average Variable Cost), karena pada kondisi tersebut tetap masih ada gunanya bagi pelaku usaha untuk berproduksi meskipun tidak ada gunanya untuk mengganti peralatan modal yang sudah rusak. Apabila suatu pelaku usaha berproduksi pada harga di bawah harga variabel rata-rata (AVC) maka dapat dikatakan bahwa harga tersebut sudah tidak wajar lagi, dan jual rugi yang dilakukan oleh pelaku usaha tersebut dapat dicurigai mempunyai maksud tertentu. $^{4}$

Menjual rugi dapat digambarkan ketika perusahaan yang memiliki posisi dominan atau kemampuan keuangan yang kuat (deep pocket) menjual produknya di bawah harga produksi dengan tujuan untuk memaksa pesaingnya keluar dari pasar. Setelah memenangkan persaingan, perusahaan tersebut akan menaikan harga kembali di atas harga pasar dan berupaya mengembalikan kerugiannya dengan mendapatkan keuntungan dari harga monopoli (karena pesaingnya telah keluar dari pasar). ${ }^{5}$

Jual rugi dalam konteks persaingan usaha merupakan tindakan pelaku usaha yang umumnya memiliki posisi dominan di pasar atau sebagai pelaku usaha incumbent menetapkan harga yang merugikan secara ekonomi dalam jangka waktu yang cukup panjang. Tindakan ini dapat mengakibatkan pesaingnya tersingkir dari pasar bersangkutan atau menghambat pelaku usaha lain untuk masuk ke pasar. ${ }^{6}$

Dalam jangka pendek, jual rugi sangat menguntungkan konsumen, namun setelah menyingkirkan pesaing dari pasar dan menghambat calon pesaing baru, pelaku usaha dominan atau pelaku usaha incumbent tersebut mengharap dapat menaikkan harga secara signifikan. Umumnya harga yang ditetapkan untuk menutupi kerugian tersebut merupakan harga monopoli (yang lebih tinggi) sehingga dapat merugikan konsumen. Praktik ini adalah upaya untuk memaksimalkan keuntungan dan menutup kerugian yang ditimbulkan ketika melakukan jual rugi.

\footnotetext{
${ }^{4}$ Mustafa Kamal Rokan, Hukum Persaingan Usaha (Teori dan Praktiknya di Indonesia) (Jakarta: PT RajaGrafindo Persada, 2010), h., 160.

${ }^{5}$ Ibid., h., 157.

${ }^{6} I b i d$, h. 158.
} 
Jual rugi belum tentu dimaksudkan untuk mematikan para pelaku usaha pesaing. Oleh karena itu harus diperhatikan, diteliti, dan dikaji secara cermat tujuan suatu pelaku usaha yang melakukan praktek jual rugi.

Pelaku usaha dapat dianggap melakukan pemasokan barang dan atau jasa dengan cara menetapkan harga yang sangat rendah apabila harga yang ditetapkan jauh lebih rendah dibandingkan dengan harga yang ditetapkan oleh sejumlah pelaku usaha lain. Sehingga hal ini harus dilakukan horizontal comparison. Suatu pelaku usaha yang melakukan pemasokan barang dan atau jasa dengan menetapkan harga yang sangat rendah, dapat dicurigai mempunyai maksud untuk menyingkirkan atau mematikan usaha pesaingnya di pasar bersangkutan, apabila dengan harga yang ditetapkannya itu tingkat keuntungan yang akan diperoleh lebih rendah.

\section{C.Jual Rugi dalam Perspektif UU No.5 Tahun 1999 dan Fiqh}

Dalam UU No. 5 Tahun 1999 Tentang Larangan Praktek Monopoli dan Persaingan Usaha Tidak Sehat ditegaskan bahwa demokrasi ekonomi dalam bidang ekonomi menghendaki adanya kesempatan yang sama bagi setiap warga negara untuk berpartisipasi di dalam proses produksi dan pemasaran barang dan jasa, dalam iklim usaha yang sehat, efektif dan efisien sehingga dapat mendorong pertumbuhan ekonomi dan bekerjanya ekonomi pasar yang wajar.

Sesuai dengan tujuan Undang-Undang tersebut yaitu mewujudkan iklim usaha yang kondusif melalui pengaturan persaingan usaha yang sehat sehingga menjamin adanya kepastian kesempatan berusaha yang sama bagi pelaku usaha besar, pelaku usaha menengah, dan pelaku usaha kecil, maka UU No. 5 Tahun 1999 mengatur beberapa perilaku dan kegiatan yang dilarang dan yang dapat mengakibatkan persaingan tidak sehat. ${ }^{7}$

Undang-undang No. 5 Tahun 1999 Pasal 20 UU menyebutkan bahwa:

“ pelaku usaha dilarang melakukan pemasokan barang atau jasa dengan cara melakukan jual rugi atau menetapkan harga yang sangat rendah dengan maksud untuk menyingkirkan atau mematikan usaha pesaingnya di pasar bersangkutan

\footnotetext{
${ }^{7}$ Abdul R. Saliman, Hukum Bisnis untuk Perusahaan Teori dan Contoh Kasus (Jakarta: Kencana Prenada, 2008), h., 226.
} 
sehingga dapat mengakibatkan terjadinya praktik monopoli dan persaingan usaha tidak sehat."

Pasal 20 tersebut dapat diuraikan ke dalam beberapa unsur, sebagai berikut: ${ }^{8}$

\section{Unsur Pelaku Usaha}

Pengertian pelaku usaha sebagai mana dimaksud dalam Pasal 1 angka 5 adalah setiap orang perorangan atau badan usaha, baik yang berbentuk badan hukum atau bukan badan hukum yang didirikan dan berkedudukan atau melakukan kegiatan dalam wilayah hukum negara Republik Indonesia, baik sendiri maupun bersama-sama melalui perjanjian, meyelenggarakan berbagai kegiatan usaha dalam bidang ekonomi.

2. Unsur Pemasokan

Pengertian memasok sebagaimana dimaksud dalam penjelasan Pasal 15 adalah menyediakan pasokan, baik barang maupun jasa, dalam kegiatan jual beli, sewa menyewa, sewa beli, dan sewa guna (leasing).

3. Unsur Barang

Pengertian barang menurut Pasal 1 angka 16 adalah setiap benda, baik berwujud maupun tidak berwujud, baik bergerak maupun tidak bergerak, yang dapat diperdagangkan, dipakai, dipergunakan, atau dimanfaatkan oleh konsumen atau pelaku usaha.

4. Unsur Jasa

Pengertian jasa menurut Pasal 1 angka 17 adalah setiap layanan yang berbentuk pekerjaan atau prestasi yang diperdagangkan dalam masyarakat untuk dimanfaatkan oleh konsumen atau pelaku usaha.

5. Unsur Jual Rugi

Jual rugi adalah harga jual yang ditetapkan oleh pelaku usaha di bawah biaya pasar.berdasarkan teori ekonomi, jual rugi adalah suatu kondisi di mana suatu pelaku usaha menetapkan harga jual dari abrang dan/atau jasa yang diproduksinya di abwah biaya total rata-rata (Average Total Cost).

6. Unsur harga yang sangat rendah

\footnotetext{
${ }^{8}$ Mustafa Kamal Rokan, Hukum Persaingan..., h., 159-162.
} 
Harga yang rendah adalah harga yang ditetapkan oleh pelaku usaha yang tidak masuk akal rendahnya.

7. Dengan maksud

Dengan maksud memiliki arti bahwa kegiatan tersebut dilakukan dengan suatu keinginan atau tujuan.

8. Unsur Menyingkirkan atau mematikan

Menyingkirkan atau mematikan berarti mengeluarkan atau menyingkirkan pelaku usaha pesaing dari pasar bersangkutan atau menjadi tutup usahanya.

9. Unsur Usaha Pesaing

Usaha pesaing adalah usaha pelaku usaha lain dalam pasar bersangkutan yang sama.

10. Unsur Pasar

Menurut Pasal 1 angka 9 pengertian pasar adalah lembaga ekonomi di mana para pembeli dan penjual baik secara langsung maupun tidak langsung dapat melakukan transaksi perdagangan barang dan atau jasa.

11. Unsur Pasar Bersangkutan

Pengertian pasar bersangkutan adalah pasar yang berkaitan dengan jangkauan atau daerah pemasaran tertentu oleh pelaku usaha atas barang dan atau jasa yang sama atau sejenis atau substitusi dari barang dan atau jasa tersebut.

12. Unsur Praktek Monopoli

Pengertian praktek monopoli menurut Pasal 1 angka 2 adalah pemusatan kekuatan ekonomi oleh satu atau lebih pelaku usaha yang mengakibatkan dikuasainya produksi dan atau pemasaran atas barang dan atau jasa tertentu sehingga menimbulkan persaingan usaha tidak sehat dan dapat merugikan kepentingan umum.

\section{Unsur Persaingan Usaha Tidak Sehat}

Pengertian persaingan usaha tidak sehat menurut Pasal 1 angka 6 adalah persaingan antar pelaku usaha dalam menjalankan kegiatan produksi dan atau pemasaran barang dan atau jasa yang dilakukan dengan cara tidak jujur atau melawan hukum atau menghambat persaingan usaha.

Selain Pasal 20, larangan penetapan harga juga diatur dalam Pasal 7 UU No. 5 Tahun1999 mengenai larangan penetapan harga di bawah harga pasar. Namun 
demikian Pasal 7 dan Pasal 20 akan diterapkan berbeda oleh KPPU tergantung pada fakta kasus per kasus. Pasal 7 mensyaratkan adanya perjanjian dengan pelaku usaha pesaingnya untuk menetapkan harga di bawah harga pasar, sedangkan Pasal 20 tidak mencantumkan adanya persyaratan perjanjian.

Untuk melaksanakan pengawasan terhadap berlakunya UU no. 5 Tahun 1999 maka pada tahun 2000 KPPU dibentuk sebagai lembaga independen yang oleh UU No. 5/1999 diberi amanat untuk mengawasi pelaksanaan undang-undang tersebut. Salah satu tugas KPPU dalam Pasal 35 adalah menyusun pedoman dan atau publikasi yang berkaitan dengan pelaksanaan UU No. 5 Tahun 1999. ${ }^{9}$

Sebelum melakukan tuduhan pada pelaku usaha yang diduga melakukan praktek predatory pricing sebaiknya terlebih dahulu dilakukan 2 (dua) tahap analisis yang berkaitan dengan diberlakukannya unreasonable price oleh pelaku usaha predator.

Pertama, mempertimbangkan karakteristik pasar, seperti konsentrasi penjual dan kondisi untuk masuk dalam pasar tersebut, yang ditunjukkan oleh adanya market power.

Kedua, memastikan bahwa tingkat harga yang diberlakukan tersebut sangat tidak masuk akal, dengan mengevaluasi perbandingan antara harga yang ditetapkan oleh pelaku usaha predator dengan biaya produksi.

Hal penting yang diperhatikan, seringkali tuduhan praktek jual rugi dicetuskan oleh suatu pelaku usaha yang merasa tersaingi oleh pesaingnya. Tuduhan predatory pricing kepada suatu pelaku usaha juga bisa dilakukan sebagai suatu strategi pelaku usaha yang kurang efisien dalam upaya mempertahankan posisi pasarnya. Hal ini dilakukan karena muncul kekhawatiran bahwa pelaku usaha yang efisien akan menurunkan harga jual barang dan jasa yang diproduksinya, dan mengambil alih pasar dari pelaku usaha-pelaku usaha yang tidak efisien. Berkaitan dengan hal tersebut, hendaknya tuduhan praktek jual rugi yang mematikan pada suatu pelaku usaha tidak dilakukan secara gegabah. Apabila terbukti bahwa pelaku

\footnotetext{
${ }^{9}$ Ada dua alasan dalam pembentukan lembaga KPPU ini, yaitu: pertama, alasan filosofis yang dijadikan dasar pembentukannya, yaitu dalam mengawasi pelaksanaan suatu aturan hukum diperlukan suatu lembaga yang mendapat kewenangan dari negara. Kedua, alasan sosiologis, alasan sosiologisnya adalah karena menurunnya citra pengadilan dalam memeriksa dan mengadili suatu perkara, serta beban perkara pengadilan yang sudah menumpuk. Lihat, Suyud Margono, Hukum Praktik Monopoli dan Persaingan Usaha Tidak Sehat (Jakarta: PT Sinar Grafika 2009), h., 127.
} 
usaha tersebut betul-betul telah menyingkirkan pelaku usaha lain yang sama efisiennya atau bahkan lebih efisien, dan terbukti kemudian menaikkan harga secara signifikan, maka tuduhan tersebut harus ditindak lanjuti.

Ketentuan pasal-pasal dalam UU No. 5 Tahun 1999 menggunakan dua pendekatan, yakni secara per se illegal $^{10}$ dan secara rule of reason. Pendekatan rule of reason adalah suatu pendekatan yang digunakan oleh lembaga otoritas persaingan usaha (dalam hal ini KPPU) untuk membuat evaluasi mengenai akibat perjanjian atau kegiatan usaha tertentu, guna menentukan apakah suatu perjanjian atau kegiatan tersebut bersifat menghambat atau mendukung persaingan. Sebaliknya, pendekatan per se illegal adalah menyatakan setiap perjanjian atau kegiatan usaha tertentu sebagai ilegal, tanpa pembuktian lebih lanjut atas dampak yang ditimbulkan dari perjanjian atau kegiatan usaha tersebut.

Keunggulan pendekatan secara rule of reason adalah, menggunakan analisis ekonomi untuk mencapai efisiensi guna mengetahui dengan pasti, yaitu apakah suatu tindakan pelaku usaha memiliki implikasi kepada persaingan atau mungkin mendorong persaingan. Dibalik kerugian yang timbul akibat praktek predatory pricing, sebenarnya terdapat sedikit keunggulan, yaitu meningkatnya upaya perbaikan kualitas produk yang beredar sehingga berimplikasi pada kepuasan konsumen yang tentu akan memberikan produk-produk yang berkualitas di pasar. Hal demikian tidak dapat terjadi jika praktek predatory pricing tidak menggunakan pendekatan secara rule of reason. Artinya, bukan tidak mungkin kebijakan menjual rugi yang dilakukan oleh pelaku usaha tertentu memotivasi para pelaku usaha pesaing untuk berlomba-lomba meningkatkan kualitas produk mereka demi menjaga loyalitas konsumen dan eksistensi perusahaan di mata publik.

Akibat hukum terhadap pelaku usaha yang melakukan praktik jual rugi menurut Pasal 20 Undang-undang No.5 Tahun 1999 maka sesuai dengan Pasal 47 UU No 5 Tahun 1999, dikenakan sanksi administratif berupa: perintah kepada

\footnotetext{
${ }^{10}$ Pendektan per se disebut juga per se ilegal, per se rules, per se doctrine dan juga per se violation. Larangan-larangan yang bersifat per se adalah larangan yang bersifat jelas, tegas dan mutlak dalam rangka memberi kepastian bagi para pelaku usaha. Pendekatan per se ilegal merupakan sebuah pendekatan di mana suatu perjanjian atau kegiatan usaha dilarang karena dampak dari perjanjian tersebut telah dianggap jelas dan pasti mengurangi atau menghilangkan persaingan. Bukti yang diperlukan adalah bahwa perjanjian yang dimaksud telah benar adanya atau bahwa kegiatan bisnis dimaksud telah benar-benar dilakukan oleh pelaku usaha perseorangan. Lihat, Mustafa Kamal Rokan, Hukum Persaingan Usaha..., h. 60.
} 
pelaku usaha untuk menghentikan kegiatan yang terbukti menimbulkan praktek monopoli dan atau persaingan usaha tidak sehat dan atau merugikan masyarakat (Pasal 47 ayat (2) butir c), dan atau penetapan pembayaran ganti rugi (Pasal 47 ayat (2) butir f) dan atau pengenaan denda dalam jumlah antara Rp.1000.000.000,00 (satu miliar rupiah dan setinggi-tingginya Rp. 25.000.000.000,00 (dua piluh lima miliar rupiah) (Pasal 47 (2) butir g), dan juga dikenakan sanksi pidana sesuai pasal 48 yaitu pengenaan denda dalam jumlah antara Rp.1000.000.000,00 (satu miliar rupiah dan setinggi - tingginya Rp. 25.000.000.000,00 (dua piluh lima miliar rupiah) atau pidana kurungan pengganti denda selama - lamanya 5 bulan (Pasal 48 ayat 2). Selain itu juga dikenakan sanksi pidana tambahan yaitu berupa: Pencabutan izin usaha, larangan kepada pelaku usaha yang telah terbukti melakukan pelanggaran terhadap UU No. 5 Tahun 1999 untuk menduduki jabatan direksi atau komisaris antara 2 (dua) tahun sampai dengan 5 (lima) tahun atau penghentian kegiatan atau tindakan tertentu yang menyebabkan timbulnya kerugian pada pihak lain.

Praktek predatory pricing selain mematikan persaingan usaha juga membahayakan konsumen karena bisa jadi pelaku usaha hanya mementingkan kuantitas konsumen dengan cara menarik keuntungan sebanyak-banyaknya melalui penawaran harga produk yang di bawah harga pasar tanpa mementingkan kualitas produk yang ditawarkan.

Dalam hal ini selain merugikan para pelaku usaha, praktek predatory pricing seiring berjalannya waktu juga berpotensi merugikan konsumen. Sehingga secara sah dan meyakinkan, praktek predatory pricing merupakan suatu kegiatan yang bertentangan dengan tujuan dibentuknya UU No. 5 Tahun 1999 yakni dapat mengganggu kepentingan umum.

Predatory pricing biasanya dilarang bukan dikarenakan menetapkan harga yang terlalu rendah terhadap produk yang dijualnya sekarang, tetapi dikarenakan di masa yang akan datang pelaku usaha akan berusaha untuk mengurangi produksinya dan menaikan harga. Oleh karena itu apabila pelaku usaha yang melakukan praktek predatory pricing, namun tidak mengurangi produksinya dan juga tidak menaikan harga, maka mungkin tidak akan terjadi predatory pricing yang bertentangan dengan hukum. 
Pada dasarnya Islam tetap memiliki prinsip kebebasan dalam melakukan berbagai kegiatan mu'amalah (perekonomian) termasuk di dalamnya kegiatan pemasaran dan persaingan. Manusia boleh membeli, menjual, serta tukar-menukar barang dan jasa. Islam melarang penentuan harga dan menentang seseorang yang memakan harta sesamanya dengan jalan yang batil.

Konsep Islam menegaskan bahwa pasar harus berdiri di atas prinsip persaingan bebas (perfect competition). Namun demikian bukan berati kebebasan tersebut berlaku mutlak, akan tetapi kebebasan yang sesuai dengan syari'ah. Konsep Islam memahami pasar dapat berperan efektif dalam kehidupan ekonomi apabila prinsip persaingan bebas dapat berlaku secara efektif. Pasar tidak mengharapkan adanya intervensi dari pihak manapun tak terkecuali negara dengan otoritas penentuan bunga atau private sektor dengan monopolistik ataupun lainnya. ${ }^{11}$

Persaingan merupakan kondisi real yang dihadapi setiap orang di masa sekarang. Kompetisi dan persaingan tersebut bisa dihadapi secara positif atau negatif, bergantung pada sikap dan mental dalam memaknai persaingan tersebut. Persaingan merupakan semacam upaya untuk mendukuki posisi yang lebih tinggi di dalam dunia usaha. Bila jumlah pesaing cukup banyak dan seimbang, persaingan akan tinggi sekali karena masing-masing pedagang memiliki sumber daya yang relatif sama. Apabila jumlah pesaing sama tetapi terdapat perbedaan sumber daya, maka terlihat mana yang akan menjadi market leader, dan pedagang mana yang merupakan pengikut. ${ }^{12}$

Islam menyambut baik sistem persaingan yang sportif tanpa dikeruhkan oleh praktik-praktik monopoli dan penimbunan, sebuah persaingan ketika harga barang tertentukan sesuai dengan aktivitas tawar-menawar antara penjual dan pembeli tanpa ada campur tangan negara. Dalam dunia bisnis seorang pedagang tampaknya tidak dapat terpisahkan dari aktivitas persaingan. Dengan kata lain aktivitas bersaing dalam bisnis antara pedagang satu dengan pedagang yang lain tidak dapat dihindarkan. Para pedagang harus memahami dalam ajaran Islam dianjurkan agar para umatnya untuk melakukan perlombaan dalam mencari kebaikan di segala hal,

\footnotetext{
${ }^{11}$ Ahmad Dakhoir,dan Itsla Yunisva Aviva, Ekonomi Islam dan Mekanisme Pasar (Refleksi Pemikiran Ibn Taimiyah) (Jakarta: Laksbang Pressindo, 2017), h., 6.

${ }^{12}$ Jopie Jusuf, Analisis Kredit untuk Account Officer (Jakarta: PT. Gramedia Pustaka Utama, 2008), h., 260.
} 
termasuk di antaranya dalam hal berbisnis. Oleh karena itu, walaupun sedang mengalami kondisi persaingan, pedagang muslim bisa berusaha menghadapinya dan tanpa merugikan orang lain. Islam sebagai sebuah aturan hidup yang khas, telah memberikan aturan-aturan yang rinci untuk menghindarkan munculnya permasalahan akibat praktik persaingan yang tidak sehat.

Tiga unsur yang harus dicermati dalam persaingan bisnis adalah: ${ }^{13}$

1. Pihak-pihak yang bersaing

Manusia merupakan pelaku bisnis. Bagi seorang muslim, bisnis yang dilakukan adalah untuk memperoleh dan mengembangkan harta yang dimilikinya. Harta yang diperolehnya adalah rezeki yang diberikan Allah swt. Tugas manusia adalah berusaha sebaik-baiknya salah satunya dengan jalan bisnis. Tidak ada anggapan rezeki yang diberikan Allah swt. akan diambil oleh pesaing. Karena Allah swt. telah mengatur hak masing-masing sesuai usahanya.

2. Segi cara bersaing

Berbisnis adalah bagian dari muamalah, karenanya bisnis tidak lepas dari hukum-hukum yang mengatur muamalah. Dalam berbisnis setiap orang akan berhubungan dengan pesaing. Rasulullah saw. memberikan contoh bagaimana bersaing dengan baik. Ketika berdagang, Rasul tidak pernah melakukan usaha untuk menghancurkan pesaingnya. Dalam berbisis, harus selalu berupaya memberikan pelayanan terbaik, namun tidak menghalalkan segala cara.

3. Objek yang dipersaingkan

Beberapa keunggulan yang dapat digunakan untuk meningkatkan daya saing adalah:

a. Produk

Produk yang dipersaingkan baik barang dan jasa harus halal. Spesifikasinya harus sesuai dengan apa yang diharapkan konsumen untuk menghindari penipuan, kualitasnya terjamin dan bersaing.

b. Harga

\footnotetext{
${ }^{13}$ Ismail Yusanto, Menggagas Bisnis Islami (Jakarta: Gema Insani Press, 2002), h., 92-97.
} 
Apabila ingin memenangkan persaingan, harga produk harus kompetitif. Dalam hal ini, tidak diperkenankan membanting harga untuk menjatuhkan pesaing.

c. Tempat

Tempat yang digunakan harus baik, sehat, bersih dan nyaman, dan harus dihindarkan dari hal-hal yang diharamkan seperti barang yang dianggap sakti untuk menarik pengunjung.

d. Pelayanan

Pelayanan harus diberikan dengan ramah, tapi tidak boleh dengan cara yang mendekati maksiat.

Dalam kegiatan bisnis, pedagang harus bisa menghadapi persaingan usaha yang lazim terjadi dalam dunia bisnis. Ketika pedagang bersikap kompetitif maka pedagang memiliki sikap siap serta berani bersaing dengan orang lain. Dalam arti yang positif dan optimis, kompetisi bisa diarahkan pada kesiapan dan kemampuan untuk mencapai kemajuan dan kesejahteraan sebagai umat manusia. Kompetisi seperti ini merupakan motivasi diri sekaligus faktor penggali dan pengembang potensi diri dalam menghadapi bentuk-bentuk kompetisi, sehingga kompetisi tidak semata-mata diarahkan untuk mendapatkan kemenangan dan mengalahkan lawan. ${ }^{14}$

Dalam penentuan harga di pasar bisa di katakan tidak adanya asas untuk menentukan harga di pasaran apalagi oleh pemerintah sehingga bisa dikatakan tidak ada juga harga yang di bawah pasaran, seperti yang terjadi pada zaman Rasulullah saw. yang disebutkan dalam hadis:

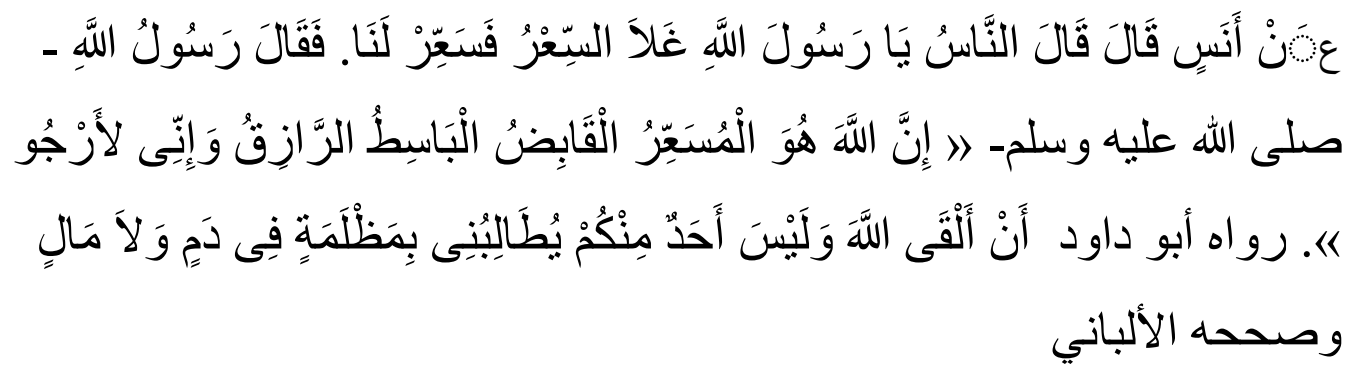

Dari sahabat Anas, ia menuturkan, "Para sahabat mengeluh kepada Rasulullah shallallahu 'alaihi wa sallam, dan mereka berkata, 'Wahai Rasulullah, sesungguhnya harga barang kebutuhan sekarang ini begitu mahal. Alangkah

\footnotetext{
${ }^{14}$ Muhammad Saman, "Persaingan Industri PT. Pancanata Centralindo Perspektif Etika Bisnis Islam" (Skripsi--Universits Islam Negeri Syarif Hidayatullah, Jakarta, 2010), h.19.
} 
baiknya bila Anda membuat menentukan harga.' Menanggapai permintaan sahabatnya ini, Rasulullah bersabda, 'Sesungguhnya Allah-lah yang menentukan harga, serta mengencangkan, melapangkan, dan memberi rezeki. Dan sesungguhnya, aku berharap untuk menghadap Allah tanpa ada seorang pun yang menuntutku karena suatu kezaliman, baik dalam urusan darah (jiwa) atau pun harta."' (HR. Abu Daud; oleh Al-Albani dinyatakan sebagai hadits sahih).

Hadits tersebut mengandung pengertian mengenai keharaman penetapan harga, walaupun dalam keadaan harga-harga sedang naik, karena jika harga ditentukan murah akan dapat menyulitkan pihak penjual. Sebaliknya, menyulitkan pihak pembeli jika harga ditentukan mahal. yang dimaksud oleh hadis di atas, bukan berarti mutlak dilarang menetapkan harga, sekalipun dengan maksud demi menghilangkan bahaya dan menghalangi setiap perbuatan zalim. Bahkan menurut pendapat para ahli, bahwa menetapkan harga itu ada yang bersifat zalim dan terlarang, dan ada pula yang bijaksana dan halal. Oleh karenanya, jika penetapan harga itu mengandung unsur -unsur kezaliman dan pemaksaan yang tidak betul; yaitu dengan menetapkan suatu harga yang tidak dapat diterima, atau melarang sesuatu yang oleh Allah swt. dibenarkan, maka jelas penetapan harga semacam itu hukumnya haram.Tetapi jika penetapan harga itu penuh dengan keadilan, misalnya dipaksanya mereka untuk menunaikan kewajiban membayar harga mitsil dan melarang mereka menambah dari harga mitsil, maka hal ini dipandang boleh.

Perdagangan itu adalah untuk mencari keuntungan, di antara cara manjur untuk mewujudkan untung ialah dengan menguasai harga jual atau harga beli. Semakin seseorang memiliki keleluasaan mengatur harga jual atau beli, semakin besar keuntungannya. Di antara ulah nakal sebagian orang guna mewujudkan keuntungan pribadi, walau dengan mengorbankan kepentingan masyarakat luas, adalah menjatuhkan harga jual barang. Dengan jatuhnya harga jual barang, akan banyak pedagang atau produsen yang berguguran. Dan apabila hal itu benar-benar terjadi, hanya para pedagang dengan modal besar yang mampu bertahan dan akhirnya menguasai pasar. Dan apabila pasar telah dikuasai segelintir pedagang, mereka akan dengan leluasa mempermainkan harga.

Islam membolehkan para pedagang untuk berkompetisi bukan berarti mengizinkan mereka saling membunuh dan menjatuhkan. Yang demikian itu, 
mengingat Allah swt. telah menentukan rezeki masing-masing manusia, tanpa terkecuali para pedagang. Karenanya tidak pantas khawatir jatah rezeki hilang atau terkurangi oleh orang lain.

Para pedagang melakukan praktek banting harga yang dapat menimbulkan persaingan yang tidak sehat serta dapat mengacaukan stabilitas harga pasar. Dalam hal ini, pemerintah berhak memerintahkan para pedagang tersebut untuk menaikkan kembali harganya sesuai dengan harga yang berlaku di pasar. Apabila mereka menolaknya, pemerintah berhak mengusir para pedagang tersebut dari pasar. Hal ini pernah dipraktekkan Umar bin al-Khattab di mana beliau pernah mendatangi suatu pasar dan menemukan bahwa Habib bin Abi Balta' menjual anggur kering dengan harga di bawah harga pasar maka Umar langsung menegurnya: "Naikkan hargamu atau tinggalkan pasar ini." ${ }^{15}$

Praktek-praktek semacam itu sering berubah menjadi kompetisi kurang sehat yang berujung pada tersingkirnya pengusaha kecil yang bermodal kecil. Menurut pendapat mazhab Imam Malik, fakta di atas sudah cukup menjadi alasan untuk mengharamkan perilaku tersebut.

Lebih lanjut, Imam Malik mengatakan: “barang siapa menurunkan harga pasar, maka hendaklah ia diusir, karenanya, jika terdapat pelaku usaha yang menjual dengan harga dibawah pasar untuk kepentingannya sendiri, maka ia boleh dipaksa untuk menyesuaikan dengan harga pasar atau diusir dari pasar""16

Praktek banting-bantingan harga sangat merugikan dan mengancam eksistensi pengusaha. Wajar apabila praktek semacam ini dilarang dalam Islam, sebagaimana dijelaskan oleh Imam Ibnul Qayyim pada penggalan ucapan beliau berikut ini: "Nabi shallallahu 'alaihi wa sallam melarang kita memakan makanan kedua orang yang berlomba-lomba (dalam jamuan tamu atau lainnya) (HR Abu Dawud dan lainnya)

\footnotetext{
${ }^{15}$ Perekonomian yang berlaku saat itu adalah perekonomian Islami yang berpegang pada konsep price of the equivqlent, yaitu yang terjadi pada struktur pasar yang kompetitif. Dalam pasar yang kompetitif menjual di bawah harga pasar merupakan strategi predatory pricing (jual rugi agar pesaing lain keluar dari pasar dan selanjutnya menaikkan harga untuk keuntungan di atas keuntungan normal. Ibid., h.189.
}

${ }^{16}$ Mustafa Kamal Rokan, Persaingan Usaha..., h. 47 
Yang dimaksud dengan kedua orang yang berlomba-lomba pada hadits ini ialah dua orang yang masing-masing dari keduanya berusaha untuk mengungguli kawannya dalam hal donasi. Misalnya keduanya membuat jamuan yang mewah untuk mengungguli jamuan yang disajikan oleh kawannya, ataupun perlombalombaan dalam hal jual beli. Masing-masing dari penjual memberikan potongan harga pada barang dagangannya, agar para konsumen tidak membeli dari penjual lainnya.

Salah satu pandangan Imam Hambali adalah pendekatan Islami untuk memelihara persaingan yang adil di pasar. Imam Hambali mencela pembelian dari seorang penjual yang menurunkan harga barang untuk mencegah orang membeli barang yang sama dari saingannya. Alasan beliau adalah jika penurunan harga barang seperti ini dibiarkan, maka akan menempatkan penjual yang menurunkan harga tersebut pada posisi monopoli yang akhirnya dapat menetapkan harga semaunya. Imam Ahmad dengan tegas membenci praktek semacam ini, dan membenci konsumen yang membeli dari keduanya. Larangan ini bertujuan untuk mencegah terjadinya dua hal:

1. Mencegah masyarakat dari memakan harta kedua orang yang berlomba-lomba tersebut. Karena membeli dagangan atau memakan jamuan mereka dapat menjadikan mereka merasa puas sehingga menjadikan mereka semakin hanyut dan terus menerus dalam perbuatan yang dibenci oleh Allah swt. dan RasulNya semacam ini.

2. Dengan meninggalkan hidangan keduanya dan tidak membeli dari keduanya maka keduanya akan segera menghentikan perlombaan mereka yang tercela ini.

Islam mengatur dan mengawasi pasar secara ketat, salah satu lembaga yang semestinya dibentuk untuk mengawasi pasar menurut Islam adalah Hisbah. Meskipun demikian sebenarnya pengawasan dapat dilakukan oleh semua orang sebagaimana sabda Rasulullah saw. tentang perintah untuk menindak kemungkaran. Terkait dengan mencegah terjadinya kemungkaran ini salah satu wewenang lembaga hisbah adalah pencegahan penipuan di pasar, seperti masalah kecurangan dalam timbangan, ukuran maupun pencegahan penjualan barang yang rusak serta tindakan-tindakan yang merusak moral. 


\section{Jual Rugi pada Usaha Fotocopi Di lingkungan IAIN Langsa}

Usaha fotocopy merupakan kelompok usaha kecil, bisa juga dikatakan dalam bentuk perusahaan perseorangan. Untuk mendirikan usaha fotocopy tidak memerlukan persyaratan khusus, sebagaimana bentuk badan hukum lainnya. Pendirian usaha fotocopy tidak memerlukan modal besar. Pendiriannya mudah dan tidak diperlukan organisasi besar, tetapi cukup dengan organisasi dan manajemen yang sederhana.

Berdasarkan pengamatan di lapangan tentang usaha fotocopy di lingkungan kampus IAIN Langsa permintaan akan jasa foto copy semakin meningkat seiring dengan meningkatnya kebutuhan masyarakat khususnya para pelajar dan mahasiswa, terhadap salinan data dalam jumlah yang banyak dan siap dalam waktu yang singkat.

Pada awalnya kampus tersebut namanya masih STAIN dan pada saat itu usaha fotocopy di sekitar kampus masih sedikit kira-kira 7 orang. Setelah STAIN berubah menjadi IAIN dan pendaftaran mahasiswa pun sudah dilakukan dengan jalur online maka otomatis mahasiswa bertambah banyak, dan ditambah lagi kampus ini bersebelahan dengan kampus UNSAM (Universitas Samudera), maka para pengusaha melihat lingkungan ini adalah lingkungan yang sangat bagus untuk membuka usaha fotocopy. Sekarang diperkirakan jumlah usaha fotocopy lebih kurang 23 orang dengan persaingan usaha yang sangat ketat.

Perkembangan penawaran di sektor usaha fotocopy pada saat ini memang masih berada di lingkungan kampus, yang pada umumnya membutuhkan keberadaan penyedia jasa fotocopy. Sebagai langkah awal menarik konsumen, dapat diawali dengan promo harga yang lebih murah. Selanjutnya, agar usaha fotocopy menjadi lebih baik maka perlu peningkatan penawaran yang memberikan nilai lebih bagi konsumen dengan cara mendiskon harga dengan ketentuan yang berlaku.

Mengingat adanya peluang yang besar dalam usaha foto copy pada masa yang akan datang, maka perlu adanya penawaran produk yang memberikan nilai lebih dan manfaat bagi konsumen. Penawaran tersebut dapat ditingkatkan menjadi lebih variatif (lebih banyak produk yang ditawarkan dalam hal ini tidak dimiliki 
oleh pesaing) dan juga lebih kompetitif (dilihat dari kualitas kertas yang digunakan dan hasil copy).

Usaha Jasa Fotocopy di lingkungan kampus IAIN Langsa ini di samping menyediakan jasa fotocopy juga menyediakan jasa print, pengetikan, atk, cetak foto, penjilidan, laminating dan lain-lain yang merupakan aktivitas yang dekat dengan mahasiswa dan memang dibutuhkan mahasiswa untuk menunjang kegiatan perkuliahannya, sehingga kebutuhan mahasiswa akan usaha ini cukup tinggi

Standar tarif jasa fotocopy pada awalnya (tahun 2009) di lingkungan kampus IAIN Langsa ini adalah sebagai berikut: :

\begin{tabular}{|c|c|c|}
\hline No & Jenis Jasa & Tarif per lembar Rp \\
\hline 1 & Fotocopy & 150 \\
\hline 2 & Print & 1000 \\
\hline 3 & Jilid & 2000 \\
\hline 4 & Ketik & 3000 \\
\hline 5 & Laminating & 5000 \\
\hline
\end{tabular}

Standar tarif tersebut berlaku nyaman dirasakan para pengusaha fotocopy selama kurang lebih 2 tahun, sampai akhirnya datang pesaing baru yang menetapkan tarif harga jauh di bawah harga pasar yang sudah dibuat selama ini. Tarif untuk fotocopy ada yang membuat tarif Rp. 100 / lembar, yang paling turun harganya adalah pada jasa print di mana pesaing baru menetapkan harga Rp. 200 / lembar bahkan ada yang membuat harga Rp. 199 / lembar dengan membuat kartu anggota di mana nanti kartu anggota ini akan diundi pada saat -saat tertentu dan mereka akan membagi-bagikan hadiah.

Apabila dibuat perhitungan modal pada usaha fotocopy tersebut adalah:

\begin{tabular}{|c|c|c|}
\hline No & Jenis & Harga Modal \\
\hline 1 & Kertas & 100 \\
\hline 2 & Lampu & 30 \\
\hline 3 & Perbaikan Mesin & 20 \\
\hline 4 & Sewa Toko & 20 \\
\hline 5 & Karyawan & 20 \\
\hline & Jumlah & 190 \\
\hline
\end{tabular}


Harga kertas untuk bulan-bulan terakhir semakin naik karena langkanya pasaran kertas, Apalagi kertas yang selama ini bagus dan murah sudah dihilangkan dari pasaran. Demikain juga dengan lampu, yang semakin naik tarifnya jadi modal yang diperlukan tidak bisa dipastikan perbulannya, dan biasanya sewa toko setiap tahunnya juga akan naik, karena para pemilik toko juga melihat adanya peluang yang besar di lingkungan tersebut.

Jumlah modal yang dikeluarkan kira-kira Rp. 190 berarti mereka yang menetapkan harga print Rp. 199,- hanya mendapatkan untung Rp. 9,- Jadi harga yang ditetapkan pesaing baru tersebut jauh dari untung, apalagi listrik yang semakin lama semakin naik harganya. Untuk menyikapi strategi pesaing baru tersebut, pesaing lama ada juga yang mengikuti strategi mereka tetapi ada juga yang tetap dengan harga lama dengan menjaga kualitas dan layanan yang baik, dan ada juga yang mengurangi harga setengahnya untuk tidak mengikuti harga pesaing baru dan tidak bertahan dengan harga lama. Jadi masing-masing pengusaha fotocopy mempunyai cara-cara sendiri dalam mempertahankan usahanya.

Ditambah lagi pesaing baru tersebut merupakan salah satu dosen di perguruan tinggi di lingkungan tersebut yang memberikan peluang bagi dia untuk membuat promosi di kampus dengan tarif barunya tersebut yang membuat mahasiswa berlomba-lomba masuk ke dalam mekanisme pasar yang telah mereka buat.

Banting-bantingan harga yang dilakukan pesaing baru tersebut jelas merugikan pengusaha lama, sesuai observasi yang penulis lakukan pengusaha lama mengeluhkan tarif yang dibuat pesaing tersebut akhirnya pendapatan mereka jauh dari cukup. Tapi tidak ada usaha yang bisa dilakukan untuk menghentikan bantingbantingan harga tersebut, karena tidak tahu mau dilaporkan kemana, akhirnya masing-masing pengusaha bertahan apa adanya dengan keuntungan yang paspasan.

Pada titik tertentu, pengusaha lama kehabisan nafas. Hal ini dikarenakan keuntungan yang didapat tidak bisa menutupi biaya operasional usahanya. Padahal, segala macam cara sudah dilakukan untuk menekan modal yang dikeluarkan. Namun, hal ini tidak membuahkan hasil yang positif. Mahasiswa tetap masuk ke 
dalam promosi usaha mereka apalagi mahasiswa tersebut sudah diikat dengan kartu anggota yang sudah mereka buat.

Setelah lama bertahan dengan mekanisme pasar tersebut, akhirnya pesaing lama ada beberapa yang menutup usahanya karena kalah bersaing dan tidak dapat mengikuti lagi arus persaingan tersebut karena sewa toko pun yang semakin mahal. Dan ternyata pesaing baru pun yang menetapkan harga dengan jual rugi tersebut dan yang telah merusak harga pasar juga ikut gulung tikar, karena tidak mampu lagi bertahan dengan keuntungan yang tidak bisa menutupi operasional yang harus dikeluarkan setiap tahunnya, ditambah lagi harga kertas yang terus melaju naik karena mungkin adanya praktek monopoli di bidang usaha kertas tersebut.

\section{E.Analisis}

Jual rugi yang dilakukan oleh pesaing baru pada usaha fotocofy di lingkungan IAIN Langsa memunculkan ketidakadilan yang dirasakan oleh pengusaha fotocopy yang lain, terutama pengusaha yang sudah lama bermain di pasar tersebut.

Salah satu penjabaran konsep adil adalah dilarangnya melakukan predatory pricing karena jual rugi yang dilakukan oleh pesaing baru pada usaha fotocopy di lingkungan IAIN Langsa memunculkan ketidakadilan yang dirasakan oleh pengusaha fotocopy yang lain. Di mana jual rugi yang mereka lakukan telah merusak mekanisme pasar yang sudah lama berjalan dengan harga yang nyaman sesuai dengan kebutuhan operasional setiap bulannya.

Jika dianalisis dari teori keadilan ${ }^{17}$ praktek jual rugi tersebut akan mendzalimi pengusaha yang lain karena seharusnya dengan terwujudnya keadilan akan menciptakan stabilitas sosial yang akan menunjang kegiatan bisnis. Sejauh prinsip keadilan dijalankan akan lahir wajah bisnis yang lebih baik dan etis. Tidak

\footnotetext{
${ }^{17}$ Berbicara masalah keadilan maka tidak dapat melupakan filsuf Yunani yaitu Plato dan Aristoteles yang telah meletakkan dasar bagi keadilan dalam kaitannya dengan hukum positif. Sebagai penganut hukum Kodrat/ hukum alam13, dimana pada saat itu gagasan tentang keadilan adalah apa yang adil menurut hukum Kodratnya dan keadilan itu harus sesuai atau menurut keberlakuan hukumnya, maka Plato melihat keadilan dari sisi ilham, sedangkan Aristoteles beranjak dari latar belakang pemikiran model-model masyarakat, politik dan Undang-undang. Aristoteles membedakan keadilan itu menjadi 2 macam: pertama, Keadilan distributif (justitia distributiva) ialah suatu keadilan yang memberikan keadilan kepada setiap orang didasarkan atas jasa-jasanya atau pembagian menurut haknya masing-masing. kedua, Keadilan kumulatif (justitia komulativa) atau keadilan korektif ialah suatu keadilan yang diterima masing-masing anggota tanpa memperdulikan jasa masing-masing (persamaan).
} 
mengherankan bahwa hingga sekarang keadilan selalu menjadi salah satu topik penting dalam etika bisnis.

Prinsip keadilan komutatif menurut Adam Smith adalah no harm, yaitu tidak merugikan dan melukai orang lain baik sebagai manusia, anggota keluarga atau anggota masyarakat baik menyangkut pribadinya, miliknya atau reputasinya.

Prinsip keadilan tukar atau prinsip pertukaran dagang yang fair, terutama terwujud dan terungkap dalam mekanisme harga dalam pasar. Dalam keadilan tukar ini, Adam Smith membedakan antara harga alamiah dan harga pasar atau harga aktual. Harga alamiah adalah harga yang mencerminkan biaya produksi yang telah dikeluarkan oleh produsen, yaitu terdiri dari tiga komponen biaya produksi berupa upah buruh, keuntungan untuk pemilik modal, dan sewa. Sedangkan harga pasar atau harga aktual adalah harga yang aktual ditawarkan dan dibayar dalam transaksi dagang di dalam pasar.

Kalau suatu barang dijual dan dibeli pada tingkat harga alamiah, itu berarti barang tersebut dijual dan dibeli pada tingkat harga yang adil. Pada tingkat harga itu baik produsen maupun konsumen sama-sama untung. Harga alamiah mengungkapkan kedudukan yang setara dan seimbang antara produsen dan konsumen karena apa yang dikeluarkan masing-masing dapat kembali (produsen : dalam bentuk harga yang diterimanya, konsumen : dalam bentuk barang yang diperolehnya), maka keadilan nilai tukar benar-benar terjadi.

Dalam konsep ekonomi Islam, pasar yang ada berdasarkan atas etika dan nilai-nilai syari'ah, baik dalam bentuk perintah, larangan, anjuran, ataupun himbauan. Pelaku pasar mempunyai tujuan utama dalam melaksanakan sebuah transaksi, yaitu mencari ridha Allah swt. demi mewujudkan kemaslahatan hidup bersama di samping juga untuk mewujudkan kesejahteraan individu.

Berbuat adil adalah suatu keharusan apalagi dalam kaitannya dengan harga. Harga yang adil menurut Ibnu Taimiyah adalah harga yang setara yaitu harga standar yang berlku ketika masyarakat menjual barang-barang dagangannya dan secara umum dapat diterima sebagai sesuutau yang setara bagi barang-barang tersebut atau barang-barang yang serupa pada waktu dan tempat yg khusus. ${ }^{18}$

\footnotetext{
${ }^{18}$ Ahmad Dakhoir dan Itsla Yunisva Aviva, Ekonomi Islam dan Mekanisme..., h. xii
} 
Harga yang adil (just price) atau harga setara dalam Islam adalah harga baku, di mana penduduk menjual barang-barang mereka dan secara umum diterima sebagai sesuatu yang setara dengan itu dan untuk barang yang sama pada waktu dan tempat yang khusus. Harga setara itu adalah sesuai dengan keinginan atau lebih persisnya harga yang ditetapkan oleh kekuatan pasar yang berjalan secara bebas antara penawaran dan permintaan.

Ketidak adilan yang dirasakan oleh pengusaha fotocopy dengan jual rugi yang dilakukan oleh pesaing baru tersebut tentu saja tidak sesuai dengan maqashid syari'ah. ${ }^{19}$ Maqashid asy-syari" ah dalam kajian ushul fiqh secara kronologis dapat dilacak dari metode-metode penemuan illat hukum dalam teori qiyas.

Maqashid asy-syari "ah dikembangkan oleh asy-Syatibi ${ }^{20}$ di mana maqashid syari'ah itu dibagi menjadi tiga aspek, yaitu bersifat dharuriyyah (keharusan), hajiyyah (kebutuhan), dan tahsiniyyah (penghiasan). Maqashid ad-dharuriyyah disebut harus karena maqashid ini tidak bisa dihindarkan dalam menopang masalih ad-din (agama dan akhirat) dan dunia, dengan pengertian bahwa jika maslahah ini dirusak maka stabilitas kehidupan dunia pun menjadi rusak. Kerusakan maslahah ini mengakibatkan berakhirnya kehidupan dunia ini dan di akhirat ia mengakibatkan hilangnya keselamatan dan rahmat. ${ }^{21}$

Aturan yang Allah swt. tetapkan kepada manusia tidak semata-mata menunjukan adanya kekuasaan Allah swt. tetapi memberikan aspek keadilan bagi kehidupan manusia, yaitu adanya kemaslahatan yang diinginkan.

\footnotetext{
${ }^{19}$ Maqashid asy-syari", maqashid asy-syari"ah, dan maqashid asy-syar"iyah mempunyai konotasi yang sama yang secara etimologi tersusun dari dua kata, yaitu maqashid dan asy-syari"ah dengan berbagai derivasinya. kata maqashid adalah bentuk jamae dari kata maqshid yang merupakan bentuk kata jadian (bentuk isim makan) dari kata kerja qashada ( $f i$ "il madhi) yang berarti bernaksud atau menunju sesuatu.. Lois Ma"luf, Al-Munjid fi al-Lughoh wa al-A "lam (Bairut: Dār al-Masyriq, 1998), h. 235; Atabik Ali dan Ahmad Zuhudi Muhdor, Kamus Kontemporer ArabIndonesia (Yogyakarta: Yayasan Ali Maksum Pondok Krapiyak, 1996), h. 1208. Kata asy-syariecah berarti kebiasaan, atau sunnah. Lois Ma ${ }^{e e} l u f$, Al-Munjid., h. 382. Dalam perkembangannya makna asy-syarieeah ditujukan pada bagaian tertentu dari ajaran Islam secara keseluruhan

${ }^{20} \mathrm{Al}$-Syatibi merupakan salah seorang pemikir ternama dalam sejarah intelektual Islam, khususnya dalam bidang fikih. Nama lengkapnya Abu Ishaq bin Musa bin Muhammad al-Lakhmi al-Gharnati asy-Syatibi. Tidak ada ahli sejarah yang mengetahui secara pasti latar belakang kehidupan dan kelahirannya, hanya saja menurut catatan sejarah ia wafat pada tanggal 8 Sya'ban 790 H (1388 M). Lihat, Euis Amalia, Sejarah Pemikiran Ekonomi Islam: Dari Klasik hingga Kontemporer, (Jakarta:Granada Press, 2007), h. 207.

${ }^{21} \mathrm{Abu}$ Ishaq Ibrahim al-Lakhmi al-Qirnati asy-Syatibi, Al-Muwafaqat fi Ushul al-Ahkam, cet ke3, jilid 1 (Bairut: Dar al-Maerifah, 1997), h. 324
} 
Masuknya teori maqashid asy-syari"ah dalam wilayah ekonomi Islam dapat ditemukan secara langsung dalam landasan etika. Para pelaku ekonomi tidak hanya dituntut untuk dapat menguasai sumber-sumber ekonomi yang strategis tetapi juga memanfaatkannya untuk kepentingan umat dengan mengacu pada kemaslahatan dharuriyah, hajiyyah, dan tahsiniyyah tersebut.

Islam menekankan pentingnya setiap individu untuk memperhatikan dan mencapai kesejahteraan dalam kehidupannya, manusia senantiasa dituntut untuk mencari kemaslahatan. Aktivitas ekonomi produksi, konsumsi, dan pertukaran yang menyertakan kemaslahatan seperti didefinisikan syariah harus diikuti sebagai kewajiban agama untuk memeroleh kebaikan di dunia dan akhirat. Kemaslahatan dalam aktifitas ekonomi mengandung makna bahwa aktifitas ekonomi yang dilakukan atas dasar maslahah akan mendatangkan manfaat dan berkah. Dengan demikian, seluruh aktivitas ekonomi yang mengandung kemaslahatan bagi umat manusia disebut sebagai kebutuhan (needs). Kebutuhan inilah yang harus dipenuhi.

Dalam perspektif ekonomi syariah, pengembangan utility diarahkan bahwa yang menjadi sifat atau kekuatan barang atau jasa untuk memenuhi kebutuhan hidup manusia di dunia adalah maslahah. Seperti yang diungkapkan al-Syatibi, kemaslahatan hanya dapat dicapai dengan memelihara lima unsur pokok kehidupan, yaitu agama, jiwa, akal, keturunan, dan harta. Untuk itu, setiap pelaku ekonomi seharusnya selalu meningkatkan maslahah yang diperolehnya. Beberapa barang atau jasa akan memiliki maslahah yang lebih besar dan yang lainnya memiliki maslahah yang lebih kecil, tergantung pada perhatian barang atau jasa tersebut dalam mempertimbangkan kelima unsur pokok kehidupan. Barang atau jasa yang menjaga kelima unsur tersebut akan memiliki maslahah yang lebih besar daripada barang atau jasa yang hanya berfungsi sebagai penghias kelima unsur tersebut. Dengan demikian, konsep maslahah merupakan konsep yang objektif terhadap perilaku konsumen karena ditentukan oleh tujuan (maqashid) syariah.

Persaingan usaha fotocopy di lingkungan IAIN Langsa dengan cara jual rugi telah merampas nasib para pengusaha lain. Ulama mengharamkan segala tindakan yang merugikan orang lain Berarti jual rugi bukan hanya merusak mekanisme pasar yang sudah baik juga memberikan mudharat kepada diri sendiri dan kepada orang lain, dengan merusak kemaslahatan jiwa dan harta. 
Pengusaha dibolehkan untuk berbeda dalam harga, namun apabila dengan maksud membahayakan orang lain, maka hal tersebut akan memberikan kerugian kepada pengusaha lain. Karena ia telah bertentangan dengan Hadis yang diriwayatkan oleh Imam Malik dalam al-Muwaththa' dari Amru bin Yahya, dari ayahnya secara mursal, dan juag diriwayatkan oleh al-Hakim dalam al-Ustadra, juga Baihaqi dan ad-Daruqthni, dari hadis Abu Sa'id al-Khudri dan diriwayatkan oleh Ibnu Majah dari hadis Ibnu Abbas dan Ubbadah bin Ash-Shamit bahwa Rasulullah saw. bersabda:

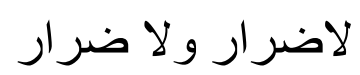

Artinya: "Tidak ada bahaya bagi diri sendiri, dan tidak ada pembahayaan bagi orang lain”. ${ }^{22}$

Jual rugi termasuk kepada tindakan-tindakan yang menimbulkan mudharat ${ }^{23}$ kepada pengusaha lain. Para pedagang sering saling menjatuhkan harga jual demi menarik konsumen sebanyak-banyaknya, dan kalau bisa sekaligus menyingkirkan seluruh kompetitornya.

Keadilan merupakan nilai paling asasi dalam ajaran islam seluruh ulama terkemuka sepanjang seajrah islam menempatkan keadilan sebagai unsur paling utama dalam maqashid syari'ah. Ibnu Taimiyahbmenyebutkan keadilan sebagai nilai utama dari tauhid sementara Muhmmad abduh mengnngap kezzaliman, sayyid qutub mengtakan keadilan ssebagai unsur pokok yang komprehenship dan terpenting dalam semua aspek kehidupan.

Dengan demikian jual rugi yang menyimpang dari ketentuan bertentangan dengan teori mashlahah al-ummah dan tidak tercapainya tujuan disyari'atkannya hukum ekonomi sesuai maqashid syari'ah.

\footnotetext{
${ }^{22}$ Dari Hadis tersebut diambillah kaidah "tidak boleh membahayakan orang lain dan membalas bahaya dengan bahaya. Lihat, Abdul Karim Zaidan, al-Wajiz: 100 Kaidah Fikih dalam Kehidupan Sehari-hari (Jakarta: al-Kautsar, 2008), h., 140 ; A. Djazuli, Kaidah-kaidah Fikih : Kaidah-kaidah Hukum Islam dalam Menyelesaikan Masalah-masalah yang Praktis (Jakarta: Kencana, 2007), h. 68.

${ }^{23}$ Mempertimbangkan kemudharatan harus memenuhi tiga hal yaitu: 1) setiap kemudharatan yang menimpa manusia secara umum adalah terlarang, 2) dalam memprtimbangkan kemudharatan berskala umum, tidak melihat kepada kepada apakah kemudharatan itu memang dimaksudkan dan disengaja ataukah tidak, akan tetapi yang dilihat adalah dampak nyata yang ditimbulkannya, 3 ) kemudharatan yang menimpa perseorangan adalah tidak dipertimbangkan kecuali jika seseorang memang bermaksud dan sengaja untuk menimpakan kemudharatan itu kepada orang lain. Lihat, Wahbah az-Zuhaili, Fiqih Islam wa Adillatuhu, terj. Abdul Hayyi al-Kattani (Jakarta: Gema Insani, 2011), h. 49.
} 


\section{F. Kesimpulan}

Jual rugi yang dilakukan oleh pengusaha fotocoy di lingkungan IAIN Langsa dilarang dalam UU No. 5 tahun 1999 dalam pasal 20 karena menimbulkan persaingan tidak sehat, dan menimbulkan kerugian kepada orang lain. Dalam persfektif fiqh jual rugi ini juga dilarang karana akan memberikan mudharat kepada orang lain, ditambah lagi dari sejarah pada masa Nabi saw. dan masa Umar bin Khattab sangat membenci pengusaha yang melakukan predatory pricing tersebut.

Jual rugi tersebut juga menimbulkan ketidakadilan di antara pengusaha fotocopy karena akan merugikan pesaing lama dan bahkan ada yang sampai gulung tikar, ketidak adilan tersebut tidak sesuai dengan konsep maqashid syariah yaitu tercapainya kemaslahatan di antara para pelaku usha fotocopy di lingkungan IAIN Langsa.

\section{DAFTRA PUSTAKA}

Amiruddin, dan H. Zainal Asikin. Pengantar Metode Penelitian Hukum. Jakarta: PT Raja Grafindo Persada, 2003.

Arfa, Faisar Ananda dan Watni Marpaung. Metodologi Penelitian Hukum Islam. Jakarta: Kencana, 2016.

A. Karim, Adiwarman. Ekonomi Mikro Islami. Jakarta: PT RajaGrafindo Persada, 2016.

A. Djazuli. Kaidah-kaidah Fikih : Kaidah-kaidah Hukum Islam dalam Menyelesaikan Masalah-masalah yang Praktis. Jakarta: Kencana, 2007.

B.N. Maribun. Kamus Manajemen. Jakarta: Pustaka Sinar Harapan, 2003. Departemen Pendidikan Nasional. Kamus Besar Bahasa Indonesia, Edisi IV. Jakarta: PT Gramedia Pustaka Utama, 2008.

Dakhoir, Ahmad dan Itsla Yunisva Aviva. Ekonomi Islam dan Mekanisme Pasar (Refleksi Pemikiran Ibn Taimiyah). Jakarta: Laksbang Pressindo, 2017.

Hafidhuddin, Didin dan Hendri Tanjung. Manajemen Syari'ah dalam Praktek. Jakarta: Gema Insani Press, 2002.

Jusuf, Jopie. Analisis Kredit untuk Account Officer. Jakarta: PT. Gramedia Pustaka Utama, 2008. 
Nugroho, Susanti Adi. Hukum Persaiangan Usaha Di Indonesia. Jakarta: Kencana, 2014.

Soekanto, Soerjono dan Sri Mamudji. Penelitian Hukum Normatif Suatu Tinjauan Singkat. Jakarta: PT RajaGrafindo Persada, 2006.

Rokan, Mustafa Kamal. Hukum Persaingan Usaha (Teori dan Praktiknya di Indonesia). Jakarta: PT RajaGrafindo Persada, 2010.

R. Saliman. Abdul. Hukum Bisnis untuk Perusahaan Teori dan Contoh Kasus. Jakarta: Kencana Prenada, 2008.

Swasta DH, Basu dan Irawan. Asas-asas Marketing. Yogyakarta: Liberty, 1964.

Siswanto, Ari. Hukum Persaingan Usaha. Jakarta: Ghalia Indonesia, 2002.

Sukirno, Sadono. Makro Ekonomi Teori Pengantar. Jakarta: PT RajaGrafindo Persada, 2013.

Sistaningrum, Widyaningtyas. Manajemen Penjualan. Kanisius: Yogyakarta, 2002.

Saman, Muhammad. Persaingan Industri PT. Pancanata Centralindo Perspektif Etika Bisnis Islam. Skripsi--Universits Islam Negeri Syarif Hidayatullah, Jakarta, 2010.

Tjiptono, Fandy. Mengenal E-Business. Yogyakarta, 2001.

Zaidan, Abdul Karim. al-Wajiz: 100 Kaidah Fikih dalam Kehidupan Sehari-hari. Jakarta: al-Kautsar, 2008.

az-Zuhaili, Wahbah. Fiqih Islam wa Adillatuhu, terj. Abdul Hayyi al-Kattani. Jakarta: Gema Insani, 2011.

Yusanto, Ismail. Menggagas Bisnis Islami. Jakarta: Gema Insani Press, 2002. 